University of Nebraska - Lincoln

DigitalCommons@University of Nebraska - Lincoln

\title{
Showy partridge pea [Chamaecrista fasciculata (Michx.) Greene] with potential for cultivation as a multi-functional species in the United States
}

\author{
J.B. Morris \\ USDA-ARS, Brad.Morris@ars.usda.gov
}

Follow this and additional works at: https://digitalcommons.unl.edu/usdaarsfacpub

Morris, J.B., "Showy partridge pea [Chamaecrista fasciculata (Michx.) Greene] with potential for cultivation as a multi-functional species in the United States" (2012). Publications from USDA-ARS / UNL Faculty. 1288.

https://digitalcommons.unl.edu/usdaarsfacpub/1288

This Article is brought to you for free and open access by the U.S. Department of Agriculture: Agricultural Research Service, Lincoln, Nebraska at DigitalCommons@University of Nebraska - Lincoln. It has been accepted for inclusion in Publications from USDA-ARS / UNL Faculty by an authorized administrator of DigitalCommons@University of Nebraska - Lincoln. 


\title{
Showy partridge pea [Chamaecrista fasciculata (Michx.) Greene] with potential for cultivation as a multi-functional species in the United States
}

\author{
J. B. Morris
}

This article is a U.S. government work, and is not subject to copyright in the United States.

Received: 28 February 2012/ Accepted: 19 June 2012/Published online: 18 July 2012

(C) Springer Science+Business Media B.V. (outside the USA) 2012

\begin{abstract}
Showy partridge pea, Chamaecrista fasciculata is used in the USA for cover cropping, ornate flowers in native gardens, honey crop, as an annual reseeding legume for restoration and conservation plantings, and wildlife food. However, its greatest potential may be as a bio-control plant for the control of mole crickets, cactus moth, and additional pest species. The United States Department of Agriculture, Agricultural Research Service, Plant Genetic Resources Conservation Unit (USDA, ARS, PGRCU) conserves 36 accessions originating from the USA.
\end{abstract}

Keywords Chamaecrista fasciculata $\cdot$ Extrafloral nectaries $\cdot$ Showy partridge pea

\section{Introduction}

Showy partridge pea, Chamaecrista fasciculata (Michx.) Greene is primarily a cross-pollinated diploid $(2 n=16)$ [Erickson and Fenster 2006] annual legume native to the eastern, midwest, and southern United States (USDA NRCS 2012). It has several additional common names including sleeping plant,

\section{J. B. Morris $(\square)$}

Plant Genetic Resources Conservation Unit, USDA, ARS,

1109 Experiment St., Griffin, GA 30223, USA

e-mail: Brad.Morris@ars.usda.gov prairie partridge pea, prairie senna, large-flowered sensitive-pea, dwarf cassia, partridge pea senna, locust weed and golden cassia.

Although partridge pea foliage is nutritious, it can be poisonous and should be considered potentially dangerous to cattle. Partridge pea leaves and seeds contain a cathartic substance. This substance is effective either in fresh plant material or in dry hay. Domestic livestock will eat partridge pea leaves. However, if large quantities are consumed, the animal may be stressed and die (Houck and Row 2006). It is also used to produce honey, but the flowers do not produce nectar.

Nectar is produced in the extrafloral nectaries and may attract ants thereby protecting the plant against insect attack (Kelly 1986). The function for these nectaries was debated until Bentley (1977) proved that the primary function of extrafloral nectar is to attract insect plant guards that protect the plants from herbivores. Root medicine derived from showy partridge pea by the Cherokee was used to keep ball players from tiring and a compound infusion was given for fainting spells (Hamel and Chiltoskey 1975). Additional ethnobotanical uses include a cold decoction of the plant used for nausea and the plant was also used as a bed for ripening persimmons by the Seminole (Sturtevant 1954). Showy partridge pea has been shown to control Staphylococcus aureus in vitro (Borchardt et al. 2008). Showy partridge pea extrafloral nectaries provide nectar needed by the parasitoid wasp, Larra bicolor. Since mole cricket populations are parasitized by L. bicolor in Florida fields consisting 
of showy partridge pea, these mole crickets were successfully reduced (Portman et al. 2010). Jezorek et al. (2011) suggests that Opuntia plants growing in close proximity to showy partridge pea had less cactus moth damage than those farther away which may be attributed to higher ant activity. Variation among showy partridge pea populations for nectary size, sugar production, nectar volume, with less variation for leaf pubescence has been found (Rios et al. 2008).

\section{Materials and methods}

All 29 showy partridge pea accessions used in this study are curated at the USDA, ARS, Plant Genetic Resources Conservation Unit (PGRCU) located in Griffin, GA, USA. The seed accessions studied were collected, donated, or developed as cultivars from the USA states of Arkansas, Florida, Georgia, Kansas, Louisiana, Mississippi, and New Jersey. These accessions were grown in the field at the USDA, ARS, PGRCU in Griffin, Georgia during 2006 and 2011.

\section{Results and discussion}

The plants were determined to be $C$. fasciculata and specimen accessions are conserved at the USDA, ARS, PGRCU in Griffin, Georgia.

Taxonomy and nomenclature

Chamaecrista fasciculata (Michx.) Greene ex Rydb. in Fl. Colorado (1906) 194; (Michx.) Greene in Pittonia 3 (17C) (1897) 242.

Syn.: Chamaecrista robusta (Pollard) Pollard ex A. Heller in Cat. N. Amer. 2 (1900) 5; Cassia robusta (Pollard) Pollard in Bull. Torrey Bot. Club 24 (1897) 150; C. fasciculata Michx. in Fl. bor.-amer. 1 (1803) 262; C. chamaecrista L. var. robusta Pollard in Bull. Torrey Bot. Club 21 (1894) 218; C. chamaecrista L. in Sp. pl. 1 (1753) nom. utique rej. 379.

Short description (see also Fernald 1950; Rutter and Rausher 2004; USDA, NRCS 2012)

Annual and suberect, 1.5-9 dm tall with usually simple, ascending branches. Branches have minutely subappressed pubescence but usually scanty with persistent and striated stipules (Fig. 1). Ten to 15 linear oblong leaflets oblique at the leaflet base and at about the third or fourth true leaf, saucer-shaped extrafloral nectaries which resemble a cup shaped gland beneath the lowest pair of leaflets are located at the base of each petiole (Fig. 2). Each nectary is approximately $0.5-4 \mathrm{~mm}$ across and can secret near $3 \mu \mathrm{L}$ of nectar per day. Since nearly all leaves have at least one nectary, more than 200 nectaries can exist on a large plant. The indeterminate flowers bloom from July to September and produce a straight fruit. Large yellow flowers are approximately $2.54 \mathrm{~cm}$ across with 2-4 flower clusters on the stem with each flower occurring on slender pedicels and the petals often have a purple or red spot at the base (Fig. 3). Each fruit consists of a $3.8-6.4 \mathrm{~cm}$ pod which splits along 2 sutures as it matures and each side of the pod develops into a spiral shape to expel the seeds away from the parent plants. Pods can range from 2.5 to $5 \mathrm{~cm}$ long and $4-4.5 \mathrm{~cm}$ wide with $4-13$ seeds produced per pod.

Distribution and uses

Chamaecrista fasciculata is distributed in the continental United States from New Mexico, Texas, Oklahoma, Kansas, Nebraska, South Dakota, eastward to include all states except New Hampshire, Vermont, and Maine (USDA and NRCS 2012). Showy partridge pea has several uses including wildlife food especially for the northern bobwhite and other quail species. It is also eaten by the greater and lesser prairie chickens, ring-necked pheasant, mallard, grassland birds, field mice, and deer. Showy partridge pea is also used as an ornamental plant in native gardens, for erosion control and restoration in disturbed areas since it can fix nitrogen (USDA NRCS 2012).

The Chamaecrista genus consists of about 330 species (Mabberley 2008) and nine of them have been reported as cultivated types (Kruse 2001). The African pantropically distributed Chamaecrista absus (L.) Irwin et Barneby species has been cultivated in Pakistan as a medicinal plant (Chaudhri 1953; Kerharo and Adam 1964; Thulin 1983; Uphof 1968). Chamaecrista apoucouita (Aublet) Irwin et Barneby is distributed throughout north-eastern South America and has been cultivated as a medicinal fruit in French Guiana (Luu 1975). Chamaecrista mimosoides (L.) Greene is distributed in tropical Asia, Africa, America, and Australia. It is cultivated as a green manure in 
Fig. 1 Plants of Chamaecrista fasciculata in the regeneration field in Griffin, Georgia (Photo J. B. Morris 2006)

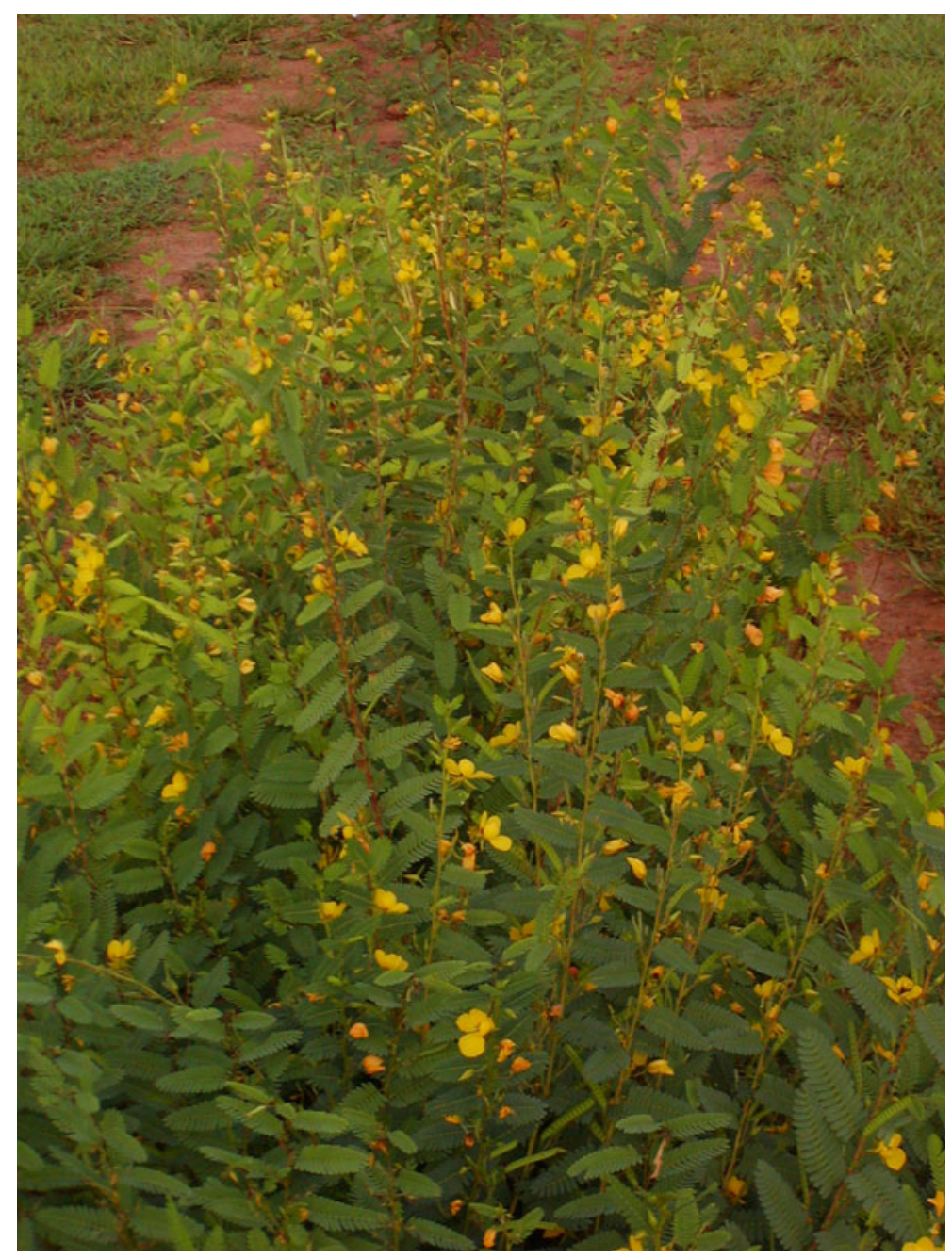

Indonesia and Taiwan, as a tea plant in Japan, and for forage in the Philippines where the roots are used for medicinal purposes and the leaves are consumed as a vegetable (Burkill 1966; Ching-chang and Chia 1965; Ducke 1925; Havard Duclos 1967; Hutchinson and Dalziel 1954; Luckow 1996; Uphof 1968; Whyte et al. 1953). However, C. diphylla Greene and C. pilosa (L.) Greene are distributed in the West Indies, Central America, northern, and north-eastern South America. Both species are planted in Venezuela for sand dune stability (Leon and Alain 1946; Tsuriell 1971). Chamaecrista nictitans (L.) Moench ssp. patellaria (DC. ex Collad.) Irwin et Barneby var. glabrata (Vogel) Irwin et Barneby is distributed throughout Mexico and South America. It is cultivated for green manure in India, Taiwan, and Indonesia while the leaves and stems are used as a substitute for tea in
Japan (Burkill 1966; Ching-chang and Chia 1965; Stone 1970; Whyte et al. 1953;). C. nictitans ssp. patellaria var. ramosa is distributed in tropical America and experimentally cultivated for green manure and soil covering in Malaysia and Indonesia (Burkill 1966; Uphof 1968; Whyte et al. 1953). The tropical Asia and Australian distributed species, C. pumila (Lam.) K. Larsen is cultivated for green manuring and soil protection (Burkill 1966; Chopra et al. 1956; Uphof 1968; Whyte et al. 1953).

Showy partridge pea has very limited cultivation on a wide scale. However, the species could be cultivated as a new multi-functional crop. For example, showy partridge pea could be grown in close proximity as a companion crop with various non-leguminous vegetables with the potential to provide added defense against insect pests. Showy partridge pea could 
Fig. 2 Ten to fifteen linear oblong leaflets oblique at the leaflet base and a cup shaped gland beneath the lowest pair (Photo D. Knauft 2008)

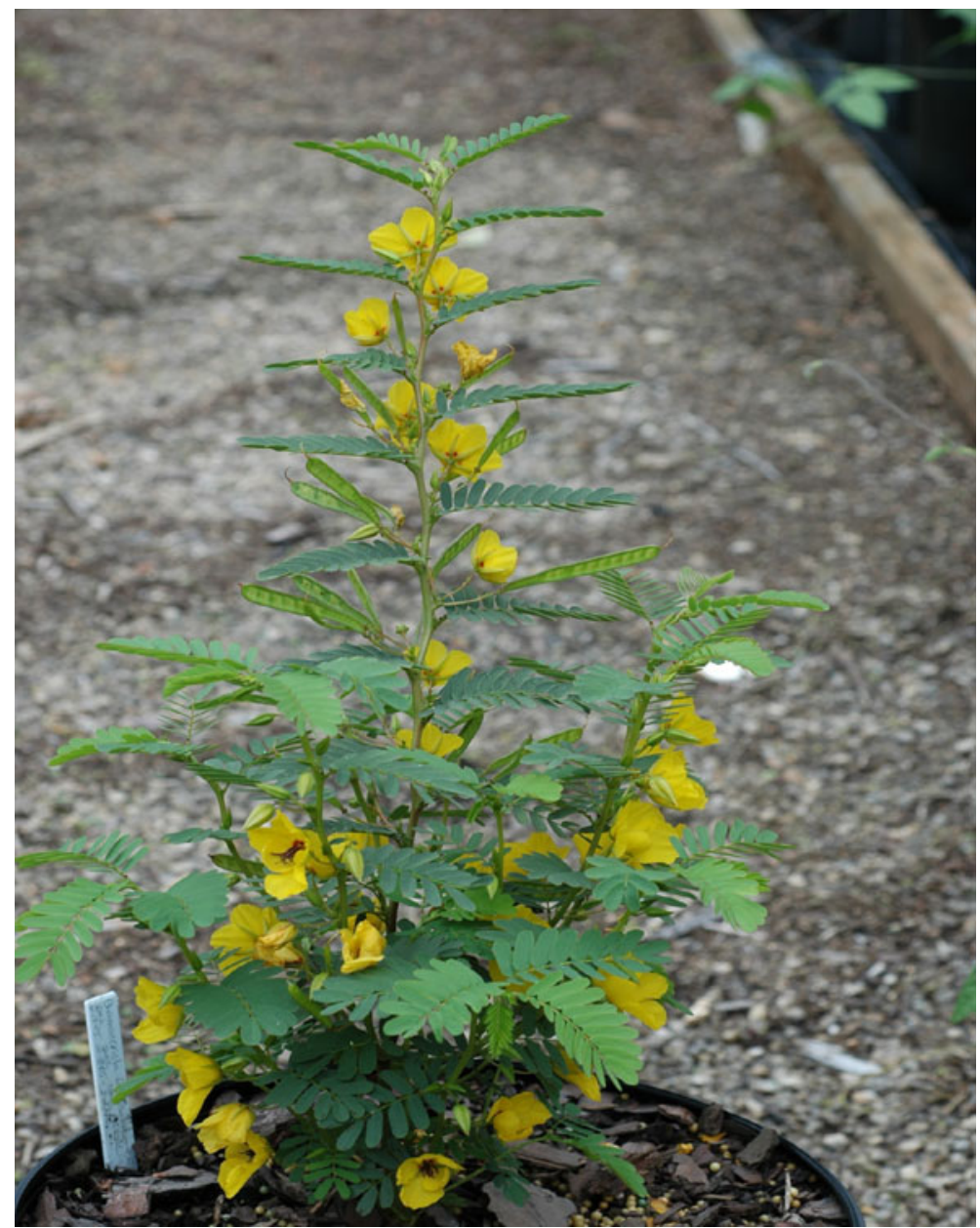

Fig. 3 Reddish spots and purple anthers are visible (Photo D. Knauft 2008)

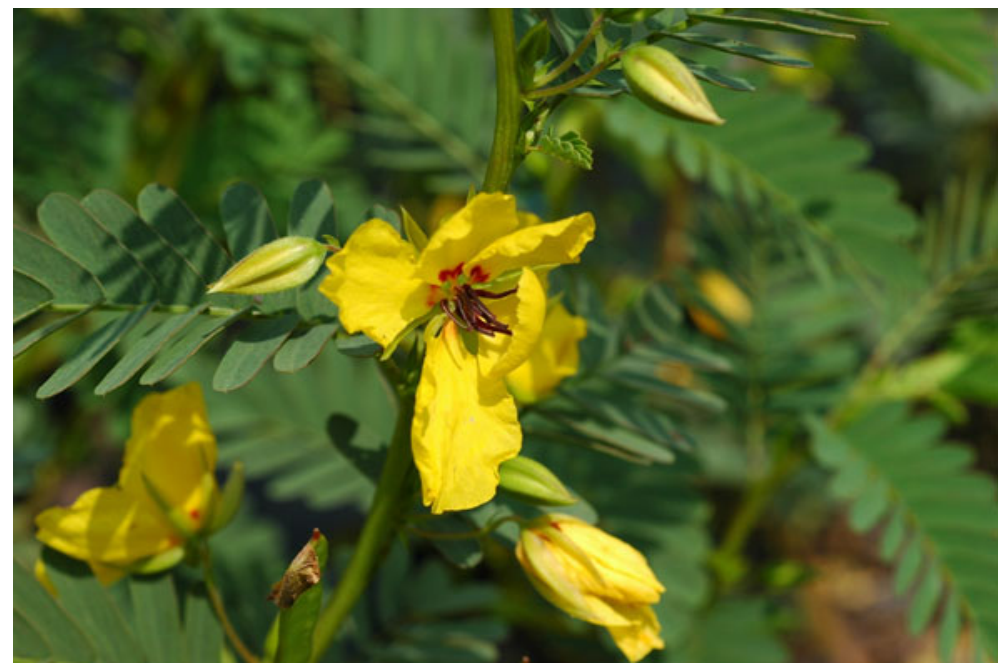

provide the food source for predator species such as ants and wasps, thereby protecting vegetable species from invading insects. Wild life viewing is popular among sports enthusiasts in the United States. Showy partridge pea could be grown in fields as food for various wild life such as wild pheasant or quail. 


\section{References}

Bentley BL (1977) Extrafloral nectarines and protection by pugnacious bodyguards. Annu Rev Ecol Syst 8:408-427

Borchardt JR, Wyse DL, Sheaffer CC, Kauppi KL, Fulcher RG, Ehlke NJ, Biesboer DD, Bey RF (2008) Antimicrobial activity of native and naturalized plants of Minnesota and Wisconsin. J Med Plants Res 2:98-110

Burkill IH (1966) A dictionary of the economic products of the Malay Peninsula, 2 Vols. Ministry Agric \& Cooperatives, Kuala Lumpur, p 2444

Chaudhri II (1953) Cultivation of medicinal plants in Pakistan. Pak J Sci Res 5:110-116

Ching-chang Chuang, Chia Huang (1965) The leguminosae of Taiwan. Animal Ind ser 7. Chinese-American Commission and Rural Reconstruction, Taipei, p 286

Chopra RN, Nayar SL, Chopra IC (1956) Glossary of Indian medicinal plants. Council Scientific Industrial Research, New Delhi, p 330

Ducke A (1925) As leguminosas do estado do para. Arch Jard Bot Rio de Janeiro 4:211-341

Erickson DL, Fenster CB (2006) Intraspecific hybridization and the recovery of fitness in the native legume Chamaecrista fasciculata. Evolution 60:225-233

Hamel PB, Chiltoskey MU (1975) Cherokee plants and their uses-a 400 year history. Herald Publishing Co, Sylva, NC, $\mathrm{p} 54$

Havard Duclos B (1967) Les plantes fourrageres tropicales: techniques agricoles et productions tropicales, collection dirigee par Rene coste X. Maisonneuve and Larose, Paris, p 397

Houck MJ, Row JM (2006) Plant Guide, Chamaecrista fasciculata, partridge pea, USDA, NRCS, Alexandria, Louisiana: Manhattan, Kansas, The Plants Database. http://plants.usda. gov/plantguide/pdf/pg_chfa2.pdf

Hutchinson J, Dalziel JM (1954) Flora of West tropical Africa, vol 1-3. Crown Agents for Oversea Governments and Administrations, London, p 574

Jezorek H, Stiling P, Carpenter J (2011) Ant predation on an invasive herbivore: can an extrafloral nectar-producing plant provide associational resistance to Opuntia individuals? Biol Invasions 13:2261-2273

Kelly CA (1986) Extrafloral nectarines: ants, herbivores and fecundity in Cassia fasciculata. Oecologia 69:600-605
Kerharo J, Adam JG (1964) Plantes medicinales et toxiques des Peul et des Toucouleur du Senegal. J Agric Trop Bot Appl 11:384-444

Kruse J (2001) Leguminosae-Caesalpinioideae. In: Hanelt P, Institute of Plant Genetics and Crop Plant Research (eds) Mansfeld's encyclopedia of agricultural and horticultural crops. Springer, Berlin, pp 568-570

Leon H, Alain H (1946) Flora de Cuba, vol 1-5. Mus Hist Nat Colegio de la Salle, La Habana, p 441, 456, 502, 556, 362

Luckow M (1996) The cultivated species of Cassia, Senna and Chamaecrista (Leguminosae). Baileya 23:195-241

Luu C (1975) Contribution a l'etude des plantes medicinales de la Guyane francaise. J Agric Trop Bot Appl 22:121-141

Mabberley DJ (2008) Mabberley's Plant-book. A portable dictionary of plants, their classification and uses, 3rd edn. Cambridge University Press, Cambridge

Portman SL, Frank JH, McSorley R, Leppla NC (2010) Nectarseeking and host-seeking by Larra bicolor (Hymenoptera: Crabronidae), a parasitoid of Scapteriscus mole crickets (Orthoptera: Gryllotalpidae). Environ Entomol 39:939-943

Rios RS, Marquis RJ, Flunker JC (2008) Population variation in plant traits associated with ant attraction and herbivory in Chamaecrista fasciculata (Fabaceae). Oecologia 156: 577-588

Rutter MT, Rausher MD (2004) Natural selection on extrafloral nectar production in Chamaecrista fasciculata: the costs and benefits of a mutualism trait. Evol 58:2657-2668

Stone BC (1970) The flora of Guam. A manual for the identification of the vascular plants of the island. Micronesica 6:1-659

Sturtevant W (1954) The Mikasuki Seminole: medical beliefs and practices. Yale University, $\mathrm{PhD}$ Thesis, p 276

Thulin M (1983) Leguminosae of Ethiopia. Opera Bot 68:1-223

Tsuriell DE (1971) Collection and conservation of desert and sand binding plants. Plant Genet Resour Newsl 25:22-25

Uphof JCT (1968) Dictionary of economic plants, 2nd edn (1st edn. 1959). Cramer, Lehre, p 591

USDA, NRCS (2012) The Plants Database (http://plants. usda.gov, 13 February 2012). National Plant Data Team, Greensboro, NC 27401-4901 USA

Whyte RO, Nilsson Leissner G, Trumble HC (1953) Legumes in agriculture. FAO Agricultural Studies 21, FAO, Rome, $367 \mathrm{p}$ 